\title{
TOLERANCE TEST ON EMBAY 8440 (PRAZIQUANTEL) FOR SCHISTOSOMIASIS JAPONICA BY DOUBLE BLIND METHOD
}

\author{
Etsuji Kamo ${ }^{1}$ AND Tatsushi Ishizaki ${ }^{2}$ \\ Received for publication 4 November 1978
}

\begin{abstract}
A newly developed anti-schistosomal drug, EMBAY 8440 (Praziquantel), by E. Merck and Bayer A. G., a marked characteristic of which consisted in the only one day administration per os, needed a tolerance test to know the side-effect in patients of schistosomiasis japonica by double blind method.

By treating these patients with $20 \mathrm{mg} / \mathrm{kg}$ dose, side-effects increased remarkably when the dose came to three times a day. The major side-effects were two, i.e., subjective complaints on the central nervous system such as mild headache or drowsiness, and a transient mild anemia in small number of cases.

However, in the evaluation of the tolerance test, there was found no poor case. The number of cases evaluated as good in the group of the true drug was significantly larger than that in the placebo group, although the number of the excellent cases was smaller in the group of the true drug than in the placebo group.

Therefore, authors concluded this remedy was clinically usable, if an attention was given to the subjective symptoms and the hemopoietic function.

The significance of results above, is that they confirmed the basis for wider applications of the drug to patients of schistosomiasis in the future.
\end{abstract}

\section{FOREWORD}

In recent years, Niridazole appeared as an internal drug which shortened the period of treatment to only five days. However, it was reported to have various side-effects by Yokogawa et al. (1969). EMBAY 8440 (hereafter abbreviated as EMBAY) has simplified the treatment to only one day in animal experiments. If such an effective drug was clinically usable, it would be indeed epoch-making.

A tolerance test on the drug to healthy volunteers in Germany showed no significant side-effect. The purpose of this work was to know whether this drug could be used to patients of schistosomiasis in Japan through the tolerance test by double blind method. And if the side-effect had been minimum, it was expected that results of the present study would be a basis of clinical application for mass treatment.

\section{Materials ANd Methods}

Subjected patients Subjected patients were 48 in total, all of them were treated at the

1 Division of Internal Medicine, Koma-Kyoritsu Hospital, Kushigata-Cho, Yamanashi-Ken, 400-03, Japan. 2 Department of Clinical Immunology, Dokkyo University School of Medicine, TochigiKen; formerly, Department of Parasitology, National Institute of Health, Tokyo. 
Koma-Kyoritsu Hospital during the period from June 1975 to March 1976.

The patients were diagnosed as chronic schistosomiasis japonica through feces examination, rectal biopsy, threshold determination for the positive skin test and the circumoval precipitin (C.O.P.) test.

As mentioning hereunder, a patient, who showed his threshold titer as $2^{3}$ or more dilution of the antigen solution for the positive skin reaction, were selected as the subjects of this study, because worms seemed to harbour in such patients at present according to Ishizaki's study (1970).

Feces examination and rectal biopsy According to MIFC technique by Blagg et al. (1955), the stool examination was performed for five consecutive days per case for detecting schistosomal eggs in feces.

By rectal biopsy, miliary mucosal fragments were removed and immediately pressed between two glass slides for microscopic examination to calculate the number of eggs in the tissue and to classify their status if fresh or old according to Prata (1957). Threshold value of skin test with the antigen of $S$. japonicum The standard solution of the antigen of Schistosoma japonicum was prepared with Melcher's method (1943): in which $30 \mathrm{mcg} / \mathrm{ml}$ of protein nitrogen from the adult worm was contained. For determining the threshold value of the positive skin reaction, a series of twofold dilutions of this antigen, which started from the standard (indicated as $2^{0}$ ) up to $2^{11}$ dilutions, was injected intradermally at the volar surface of the forearm with a quantity of $0.02 \mathrm{ml}$ per each site of injection.

Skin reaction was measured fifteen minutes after the injection and determined as positive according to Ishizaki's criterion (1970), and the highest grade of dilution of the antigen for positive reaction was decided as its threshold value.

The C.O.P. test It was performed in accordance with the original method of OliverGonzález (1954), at the Yamanashi prefectural hygiene laboratory.

Drug administration As for the way of administration of the drug, the single dose was fixed as $20 \mathrm{mg} / \mathrm{kg}$ and patients were instructed to take it with water immediately after meal. The subjects were divided at random into two major groups, A and B; placebo was administered to either of the two groups. It remained unknown till the termination of the test which of them was a true drug.

Group A and B were each subdivided into three groups, I, II and III. Group I was administered a dose of $20 \mathrm{mg} / \mathrm{kg}$ once a day, Group II $20 \mathrm{mg} / \mathrm{kg}$ twice a day, and Group III $20 \mathrm{mg} / \mathrm{kg}$ three times a day.

As shown in Table 1, Group A-I, B-I; A-II, B-II each consisted of 6 patients and Group A-III, B-III each of 12 patients for a total of 48 patients.

Clinical follow-up The general medical examination and various laboratory tests were, as a rule, performed within one week before drug administration; after drug administration, the medical examination and identical tests were conducted on the following day or within 2 or 3 days.

In the case where test values had shown abnormal changes, reexamination was performed one or two weeks later; in the case of further abnormalities, additional tests were performed as often as possible.

Standardization of those examinations were carefully made and checked with generally accepted values in Japan. 
Table 1 The outline of side-effects

\begin{tabular}{|c|c|c|c|c|c|c|c|c|c|}
\hline & Group & A-I & $\mathrm{A}-\mathrm{II}$ & A-III & Total & B-I & B-II & B-III & Total \\
\hline & Cases & 6 & 6 & 12 & 24 & 6 & 6 & 12 & 24 \\
\hline & Medication $(20 \mathrm{mg} / \mathrm{kg})$ & $\times 1$ & $\times 2$ & $\times 3$ & & $\times 1$ & $\times 2$ & $\times 3$ & \\
\hline \multirow[t]{7}{*}{ a) $s$} & Subjective symptoms & & & & & & & & \\
\hline & General (lassitude) & 0 & 0 & 0 & 0 & 1 & 1 & 2 & 4 \\
\hline & Central nervous system & 0 & 0 & $7 * *$ & 7 & 1 & 0 & $1 * *$ & 2 \\
\hline & Peripheral nervous system & 0 & 0 & 3 & 3 & 2 & 1 & 1 & 4 \\
\hline & Autonomic nervous system & 0 & 0 & 2 & 2 & 0 & 0 & 1 & 1 \\
\hline & Digestive system & 0 & 0 & 3 & 3 & 0 & 1 & 2 & 3 \\
\hline & $\begin{array}{c}\text { Total (Real number } \\
\text { of patients) }\end{array}$ & $0(0)$ & $0(0)$ & $15(9 *)$ & $15(9)$ & $4(3)$ & $3(3)$ & $7\left(3^{*}\right)$ & $14(9)$ \\
\hline \multirow[t]{6}{*}{ b) } & Medical examination & & & & & & & & \\
\hline & Pulse rate & 2 & 2 & 3 & 7 & 2 & 3 & 6 & 11 \\
\hline & Blood pressure & 3 & 1 & 2 & 6 & 2 & 0 & 2 & 4 \\
\hline & Frequency of respiration & 0 & 2 & 2 & 4 & 0 & 1 & 1 & 2 \\
\hline & Neurologic change & 4 & 3 & 12 & 19 & 6 & 3 & 11 & 20 \\
\hline & $\begin{array}{c}\text { Total (Real number } \\
\text { of patients) }\end{array}$ & $9(4)$ & $8(4)$ & $19(10)$ & $36(18)$ & $10(4)$ & $7(5)$ & $20(10)$ & $37(19)$ \\
\hline \multicolumn{10}{|c|}{ c) Laboratory change } \\
\hline & Electrocardiogram & 1 & 0 & 1 & 2 & 0 & 0 & 0 & 0 \\
\hline & Hematologic change & 1 & 3 & $4 *$ & $8 *$ & 1 & 1 & $0 *$ & $2 *$ \\
\hline & Biochemical change & 2 & 2 & 5 & 9 & 1 & 2 & 3 & 6 \\
\hline & Urinary change & 3 & 0 & 0 & 3 & 0 & 1 & 0 & 1 \\
\hline & $\begin{array}{c}\text { Total (Real number } \\
\text { of patients) }\end{array}$ & $7(5)$ & $5(4)$ & $10(9 * *)$ & $22(18 * * *)$ & $2(2)$ & $4(2)$ & $3(3 * *)$ & $9(7 * * *)$ \\
\hline $\begin{array}{r}\text { Gra } \\
(\mathrm{R}\end{array}$ & $\begin{array}{l}\text { and total } \\
\text { Real number of patients) }\end{array}$ & $16(6)$ & $13(6)$ & $44(11)$ & $73(23)$ & $16(6)$ & $14(5)$ & $30(10)$ & $60(21)$ \\
\hline
\end{tabular}

The items of clinical examinations were as follows: subjective symptoms were checked with the questionaire prepared by a research committee of this drug; routine physical examinations such as blood pressure, pulse rate, frequency of respiration and neurologic examinations etc.; and other major laboratory tests as below.

Electrocardiography ECG was diagnosed according to Minnesota Code by Rose and Blackburn (1968).

Hematological examinations Erythrocyte, leucocyte, thrombocyte and reticulocyte count, hemoglobin content, hematocrit and hemogram were examined.

Biochemical analysis of the blood It was performed in such items as SGOT, SGPT, Alkali-phosphatase, Creatin-phosphokinase, Gamma-glutamyl-transpeptidase, LDH, bilirubin, BUN, creatinine, fasting blood sugar, $\mathrm{Na}, \mathrm{K}$, total protein, protein fraction and albumin/globulin ratio.

Urinalysis Urine $\mathrm{pH}$, protein, glucose, urobilinogen, bilirubin and the sediment were examined.

Pharmacokinetic determination Blood samples for pharmacokinetic determination were obtained one hour after oral administration in Group I, one hour after the second 
administration in Group II, and one hour after the second medication and just before meal prior to the 3rd medication in Group III.

Those samples were sent to the laboratory of Bayer A.G. to determine the blood concentration level of this drug.

\section{Results}

After completion of this study, it was disclosed that Group A was treated with EMBAY itself and Group B with placebo as control.

The feature of the subjected patients

Distribution of age and sex: The age distributed from 24 to 72 years of age; the majority were in their forties to fifties. Males were larger in number than females, the ratio was 3 to 1 . The number of females in Group A was more than in B (Figure $1-\mathrm{A})$.

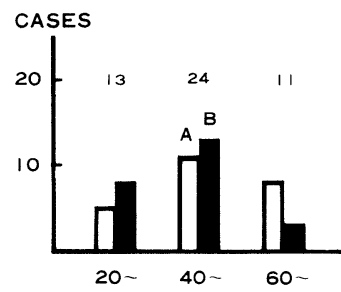

A

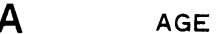

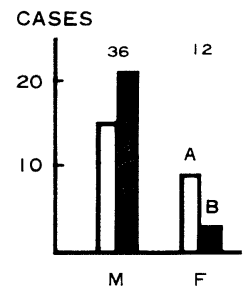

SEX

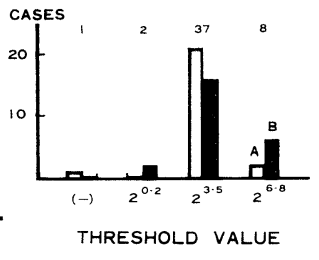

OF SKIN TEST

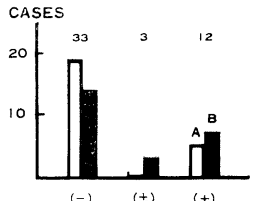

COP

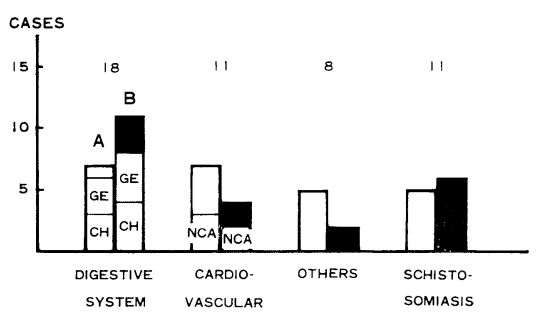

D

C RECTAL BIOPSY

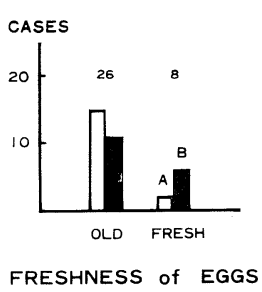

NUMBER of EGGS

COMPLICATIONS

Figure 1 Features of the subjected patients in reference to age, sex; skin test, C.O.P. test; rectal biopsy and complications.

Numbers within the figures indicate total number of cases in each group. GE: gastroenteropathy, $\mathrm{CH}$ : chronic hepatitis, NCA: neurocirculatory asthenia.

Distribution of threshold values of skin test and C.O.P. test: As for the threshold value of skin test, the majority of the cases were at $2^{3-5}$ as Figure $1-\mathrm{B}$; the positive cases in C.O.P. test were about one third of all cases.

Distribution of patients referred to the number and freshness of eggs: By rectal biopsy, in Figure 1-C, the cases with 100 or more eggs were significantly larger in number in Group B than in A. And cases with relatively fresh eggs were more in Group B than in $\mathrm{A}$. 
Stool examination: Only 4 patients were egg-positive in Group B, and no eggpositive case in A. Even in the egg-positive cases, E.P.G. (Egg per gram) was very small as 0.3 to 1.0 .

Complications in the subjected patients: The patients had various complications as chronic hepatitis, gastroenteropathy like duodenal ulcer or gastritis, and cardiovascular disease as neurocirculatory asthenia, and others. The incidence of them were much in digestive system, being followed with cardiovascular system, and 23 per cent of chronic schistosomiasis alone out of all number (Figure 1-D). There was each one case with hepatosplenomegaly in Group A and B.

Analysis of results from the tolerance study

As shown in Table 1, side-effects were summarized by case as to subjective symptoms, findings on general medical examination and laboratory tests. In this table, the real number of patients with these changes shown in brackets was often smaller than the total number of each column, because one patient showed often more than one symptom or findings in medical and/or laboratory examinations. This can be said in Table 2 similarly.

Subjective symptoms: They were analysed collectively in five categories such as general condition, central, peripheral and autonomic nervous system, and digestive system.

As shown in Table 1-a and 2-a, in Group A (EMBAY), subjective symptoms were not observed in the subgroup I $(20 \mathrm{mg} / \mathrm{kg})$ and II $(20 \mathrm{mg} / \mathrm{kg} \times 2)$, while those increased markedly in III $(20 \mathrm{mg} / \mathrm{kg} \times 3)$, where mild headache or drowsiness was predominant. However, in Group B (placebo), subjective symptoms were disseminated equally among three subgroups in small number.

That is, there was no significant difference between Group A and B in lower dosage groups (I and II). However, in the high dosage group (III), Group A had more cases complaining these symptoms compared with Group B on the whole $(9 / 12: 3 / 12, p<0.01)$. The significant difference was found particularly in the central nervous system, there being more cases in Group A-III than in B-III (7/12: $1 / 12, \mathrm{p}<0.01)$.

Drowsiness or mild headache lasted for several hours, but disappeared within a day. In one case, insomnia was complained for 4 days from the 2 nd day after medication.

The result of general medical examination: Although problems were found mainly with neurologic changes, no significant difference was observed among the groups (Table 1-b). Blood pressure, pulse rate and frequency of respiration showed no significant difference between the groups of $\mathrm{A}$ and $\mathrm{B}$.

Laboratory findings: Abnormalities were few in Group B (placebo), but they were observed in Group A (EMBAY), and increased considerably in III $(20 \mathrm{mg} /$ $\mathrm{kg} \times 3)$.

ECG There was each one case in Group A-I and A-III which showed transitory supraventricular extrasystole, while no such a case in Group B.

Hematology Table 1-c and 2-b show hematologic changes increased in the order of Group I $<$ II $<$ III in Group A (EMBAY), while there was no such tendency 
Table 2 Subjective symptoms and hematologic changes

\begin{tabular}{|c|c|c|c|c|c|c|c|c|c|}
\hline & Group & A-I & A-II & A-III I & Total & B-I & B-II & $\mathrm{B}-\mathrm{III}$ & Total \\
\hline & Cases & 6 & 6 & 12 & 24 & 6 & 6 & 12 & 24 \\
\hline \multicolumn{10}{|c|}{ a) Subjective symptoms } \\
\hline & General (lassitude) & 0 & 0 & 0 & 0 & 1 & 1 & 2 & 4 \\
\hline \multicolumn{10}{|c|}{ Central nervous system } \\
\hline & headache & 0 & 0 & 3 & 3 & 0 & 0 & 0 & 0 \\
\hline & drowsiness & 0 & 0 & 3 & 3 & 0 & 0 & 1 & 1 \\
\hline & vertigo & 0 & 0 & 0 & 0 & 1 & 0 & 0 & 1 \\
\hline & sleeplessness & 0 & 0 & 1 & 1 & 0 & 0 & 0 & 0 \\
\hline \multicolumn{10}{|c|}{ Peripheral nervous system } \\
\hline & lumbago & 0 & 0 & 2 & 2 & 1 & 1 & 1 & 3 \\
\hline & Achilles spasm and pain & 0 & 0 & 0 & 0 & 1 & 0 & 0 & 1 \\
\hline & ischias & 0 & 0 & 1 & 1 & 0 & 0 & 0 & 0 \\
\hline \multicolumn{10}{|c|}{ Autonomic nervous system } \\
\hline & short breath, hypersalivation & 0 & 0 & 1 & 1 & 0 & 0 & 0 & 0 \\
\hline & cough & 0 & 0 & 0 & 0 & 0 & 0 & 1 & 1 \\
\hline \multicolumn{10}{|c|}{ Digestive system } \\
\hline & anorexia & 0 & 0 & 0 & 0 & 0 & 0 & 1 & 1 \\
\hline & abdominal fullness & 0 & 0 & 1 & 1 & 0 & 0 & 0 & 0 \\
\hline & epigastralgia & 0 & 0 & 1 & 1 & 0 & 1 & 0 & 1 \\
\hline & Total (Real number of patients) & $0(0)$ & $0(0)$ & $13(9 *)$ & $13(9)$ & $4(3)$ & $3(3)$ & $6(3 *)$ & $13(9)$ \\
\hline \multicolumn{10}{|c|}{ b) Hematologic changes } \\
\hline & Decrease of hemoglobin & 1 & 0 & 1 & 2 & 1 & 0 & 0 & 1 \\
\hline & Erythrocytopenia & 1 & 0 & 1 & 2 & 0 & 0 & 0 & 0 \\
\hline & Decrease of hematocrit & 0 & 0 & 1 & 1 & 0 & 0 & 0 & 0 \\
\hline & Thrombopenia & 0 & 2 & 2 & 4 & 0 & 1 & 0 & 1 \\
\hline & Lymphopenia & 0 & 1 & 0 & 1 & 0 & 0 & 0 & 0 \\
\hline & Appearance of normoblast & 0 & 0 & 1 & 1 & 0 & 0 & 0 & 0 \\
\hline & Total (Real number of patients) & $2(1)$ & $3(3)$ & $6(4)$ & $11\left(8^{*}\right)$ & $1(1)$ & $1(1)$ & $0(0)$ & $2(2 *)$ \\
\hline
\end{tabular}

in Group B. These abnormal patients in Group A-III were larger in number than those in B-III $(4 / 12: 0 / 12, \mathrm{p}<0.05)$. In total number of patients with those changes, there were more abnormal cases in Group A than in B $(8 / 24: 2 / 24, \mathrm{p}<0.05)$.

Principal hematologic changes were a decrease in erythrocyte and thrombocyte count, hemoglobin content, hematocrit and relative lymphopenia as well as appearance of an orthochromatic normoblast (1\% in hemogram) in one case. However, the degree of these changes was within normal limits or slight in most cases (Table 3). Though it was impossible to follow up all cases as to the decrease in those components of the blood corpuscles, the recovery was attained within 2 or 3 months in four cases.

Biochemistry Biochemical changes were recognized in both groups A and B. However, the frequency of such abnormality is distributed evenly in each group, 
Table 3 Degrees of the hematologic changes

\begin{tabular}{|c|c|c|c|c|c|}
\hline Group & Case & Parameter & (Unit) & Change of value & Degree of change \\
\hline \multirow[t]{2}{*}{ A-I } & 06 & hemoglobin & $(\mathrm{g} / \mathrm{d} l)$ & $12.1-11.1$ & slight \\
\hline & & erythrocytes & $\left(10^{4} / \mathrm{mm}^{3}\right)$ & $413-370$ & slight \\
\hline \multirow[t]{3}{*}{$\mathrm{A}-\mathrm{II}$} & 08 & lymphopenia & $(\%)$ & $42-18$ & moderate \\
\hline & 09 & thrombopenia & $\left(10^{4} / \mathrm{mm}^{3}\right)$ & $18.0-11.0-16.0$ & slight \\
\hline & 11 & thrombopenia & & $6.4-3.1-6.9$ & moderate \\
\hline \multirow[t]{5}{*}{ A-III } & 15 & hemoglobin & & $14.5-13.5-14.8$ & within normal limits \\
\hline & & erythrocytes & & $446-398-450$ & slight \\
\hline & & hematocrit & $(\%)$ & $45-41-45$ & within normal limits \\
\hline & 16 & thrombopenia & & $19.6-10.3$ & slight \\
\hline & 18 & thrombopenia & & $10.8-8.9-14.8$ & slight \\
\hline
\end{tabular}

so that no significant difference was observed between them (Table 1-c).

Urinalysis and feces examination Urine examination also showed no significant difference between the two groups (Table 1-c).

In stool examination, no statistical comparison was made between Group A and B, because four egg-positive cases belonged only to Group B (placebo).

As a whole, in the laboratory tests, the number of patients with those changes was larger in Group A-III (EMBAY) than in B-III $(9 / 12: 3 / 12, \mathrm{p}<0.01)$; the total number of patients with laboratory changes in Group A was markedly larger than in B $(18 / 24: 7 / 24, \mathrm{p}<0.001)$.

\section{Pharmacokinetic determination}

The outline of pharmacokinetic determinations on EMBAY is illustrated in Figure 2. In Group A-I, the concentration level of EMBAY in the blood was sporadically between 0.01 and $0.65 \mathrm{mcg} / \mathrm{ml}$, half of the cases showing 0.3 to $0.4 \mathrm{mcg} /$ $\mathrm{m} l$. Considerable variations were shown despite blood samples having been collected uniformly about one hour after medication. In Group B-I, it was on the base line in most cases.

In Group A-II, the time between the initial medication and the second was mostly 4 to 5 hours. The blood level showed much variations, but it stood at 0.3 $\mathrm{mcg} / \mathrm{ml}$ in the majority of the cases. In Group B-II, it was on the base line.

In Group A-III, the initial medication was mostly carried out 4 to 5 hours before the 2nd medication. In most cases, second serum concentration level of EMBAY rose markedly after the 2nd medication comparing with initial serum, the curve of which was rather steep.

In Group B-III, the initial administration was conducted 4 to 5 hours before the second. In most cases, the serum level was on the base line, showing the lowest value.

No specific correlation was found between the concentration level of the blood and side-effects in cases of Group A (EMBAY).

Summary of the tolerance test

As for the subjective symptoms, the complaints were recognized more in A than 

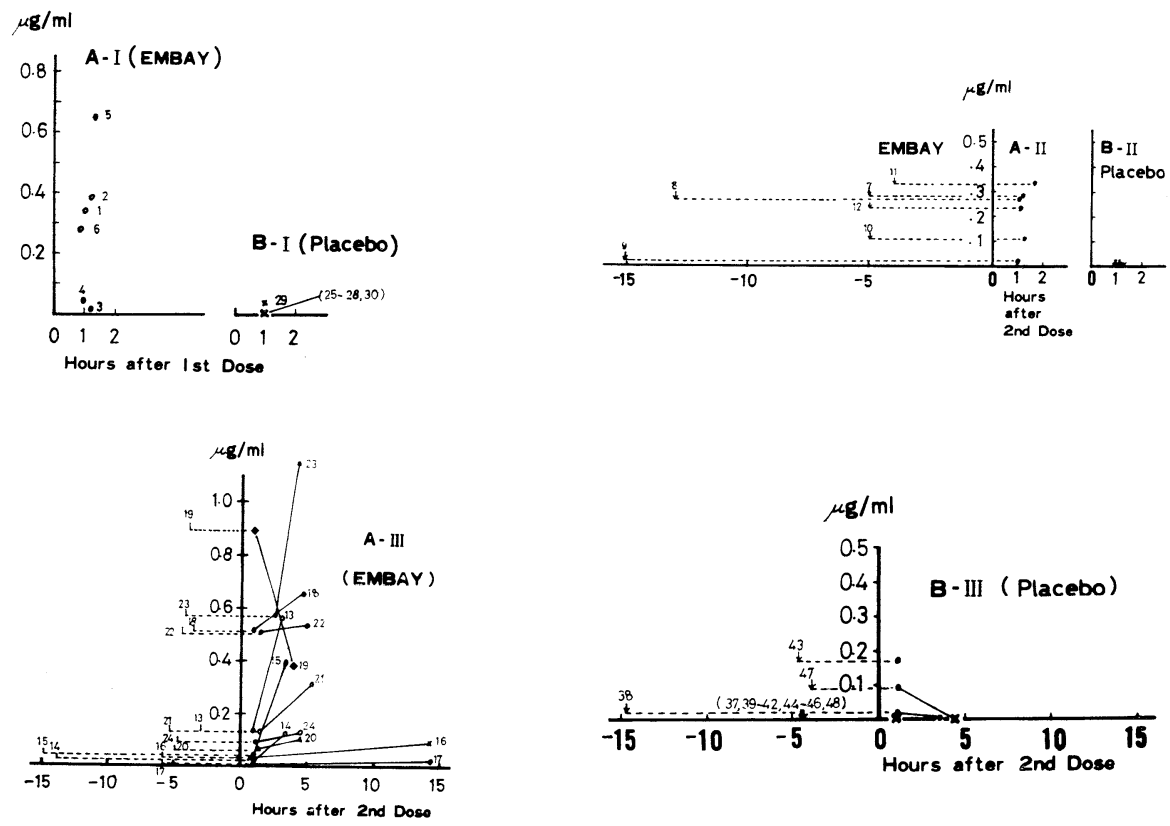

Figure 2 Blood concentration level in the EMBAY group (A), and the placebo group (B).

Small letters indicate the case numbers.

in $\mathrm{B}(\mathrm{P}<0.05)$ in Group III $(20 \mathrm{mg} / \mathrm{kg} \times 3)$, although they were few in small dosage groups regardless of $\mathrm{A}$ and $\mathrm{B}$.

There was no difference among the groups in general medical examinations. On the laboratory test, the number of patients with those changes was significantly larger in Group A-III as compared with B-III $(\mathrm{p}<0.01)$.

Nevertheless, as a whole, there was no significant difference between each subgroup of $\mathrm{A}$ and $\mathrm{B}$, with regard to the number of patients with these side-effects (Table 1).

Table 4 Evaluation of the tolerance test

\begin{tabular}{lccccccccc}
\hline & Group & A-I & A-II & A-III & Total & B-I & B-II & B-III & Total \\
Evaluation & Cases & 6 & 6 & 12 & 24 & 6 & 6 & 12 & 24 \\
Excellent & 2 & 1 & 2 & $5 *$ & 1 & 4 & 5 & $10 *$ \\
Good & 4 & $5 * *$ & 9 & $18 * *$ & 5 & $0 * *$ & 6 & $11 * *$ \\
Fair & 0 & 0 & 1 & 1 & 0 & 2 & 1 & 3 \\
Poor & 0 & 0 & 0 & 0 & 0 & 0 & 0 & 0 \\
\hline \multicolumn{1}{c}{$* 0.05, * *$} & $\mathrm{p}<0.01$ & & & & & & &
\end{tabular}

In Table 4 was shown the evaluation of tolerance test. The excellent cases in Group A (EMBAY) were fewer than those in B (5/24: 10/24, p <0.05), and the good cases in Group A were larger than those in B $(18 / 24: 11 / 24, \mathrm{p}<0.01)$. There were 
3 cases evaluated as fair in Group B (placebo), one in A. No poor case was recognized in both groups.

\section{Discussion}

The selection of the patients studied The reason of selection of the patient with a high dilution threshold value of skin test depended upon the following facts: the egg in feces was found easily in such cases by Ishizaki's study (1970); the relatively fresh ova were seen more frequently by rectal biopsy than in the case with a low dilution threshold value, and these fresh eggs were often found in the C.O.P.-positive cases according to the study of Kamo et al. (1976).

Two major side-effects There were two major side-effects in the tolerance test on EMBAY. The first was on the subjective symptoms, in which the case showing symptoms of the central nervous system (headache or drowsiness) was more in Group A-III compared with the placebo group B-III $(\mathrm{p}<0.01)$, although they were mild and transient.

The second was a hematologic change. There were significantly more cases showing changes in Group A compared with B; especially in Group A-III (EMBAY). There was noted a decrease in erythrocyte and thrombocyte count, hemoglobin content, relative lymphopenia and appearance of a normoblast (in only one case). Half of these changes, which could be followed up later, returned to the pretreatment state within 2 or 3 months. Namely, suppression to the hemopoietic function by EMBAY was suggested, but it was deemed as transient.

As above, various side-effects raised according to an increase in the number of drug administration. Nevertheless, no significant difference between Group A (EMBAY) and B (placebo) was recognized as a whole in the number of patients with these side-effects.

Pharmacokinetics There was much variations in the blood level of the drug, probably due to the individual difference in absorption. If the drug was given to an empty stomach, a uniform rise in its blood level would be obtained rapidly.

A comparison with Niridazole According to a report on Niridazole by Yokogawa et al. (1969), 14 out of 19 patients (74\%) were suffered from severe side-effects: sedatives had been used for headache and insomnia; nausea and vomiting were common; and exanthema was also recognized. Further, electrocardiographic changes were noted among two-thirds of patients.

However, in the case of EMBAY, there was no such case in which the treatment was discontinued due to side-effects. Headache was mild; no case of nausea or vomiting; epigastralgia of unknown origin in a case was somewhat accentuated temporarily. There was no case with exanthema. Electrocardiographic changes were not remarkable either. Thus, EMBAY produced only few and slight sideeffects and was much easier to use than Niridazole.

Evaluation of the tolerance test As regards the tolerance test, there was none evaluated as poor, however, good and excellent cases were more in Group A than B (23/24: $21 / 24$, no significance). This result indicated that there was no difference between EMBAY and placebo groups in evaluation. Thus, the tolerance test on EMBAY 
was very good, and it could be said that this drug is clinically usable.

\section{CONCLuSion}

A tolerance test on EMBAY 8440 was performed by means of double blind method by administering $20 \mathrm{mg} / \mathrm{kg}$ dose orally immediately after meal in a day to 48 patients with chronic schistosomiasis japonica from June 1975 to March 1976.

The subjects were patients in whom the threshold value of skin test against the antigen of $S$. japonicum was $2^{3}$ or more. They were divided into two major groups of $\mathrm{A}$ and $\mathrm{B}$; and EMBAY was given to Group A and placebo to B. Group A and B were each subdivided into Group I, II and III; Group I was administered the drug once, II twice and III three times.

As for side-effects, the following were observed.

1) As to subjective symptoms, complaints of the central nervous system such as mild headache or drowsiness were more often in the EMBAY group A-III than in the placebo group B-III $(\mathrm{p}<0.01)$.

2) On the findings of laboratory examinations, Group A-III showed more sideeffects in terms of the number of patients compared with Group B-III (9/12: $3 / 12, \mathrm{p}<0.01)$.

3) Trasient suppression to the hemopoietic function was found more in Group A (EMBAY), compared with $\mathrm{B}(\mathrm{p}<0.05)$. This tendency was particularly marked in Group A-III than in B-III (4/12:0/12, $<<0.05)$.

4) That is, when the number of the drug administration came to three, side-effects increased sharply in number.

5) Nevertheless, as a whole, there was no significant difference between each groups of Group A and B, in the total number of patients with these side-effects.

6) According to evaluation by the tolerance test, the cases evaluated as good in Group A (EMBAY) were larger in number than in the placebo group B $(18 / 24: 11 / 24, p<0.01)$, although the excellent cases in Group A were smaller than in B. There were 3 fair cases in Group B (placebo), but one in A. No poor case was found in both groups.

As described above, results of the tolerance test on EMBAY were concluded as satisfactory.

\section{ACKNOWLEDGEMENT}

The authors are indebted to Mr. M. Minai, Yamanashi Prefectural Hygiene Laboratory, and to Dr. Y. Hosaka, National Institute of Health, for the performance of the C.O.P. test.

\section{REFERENCES}

1) Blagg, W., Schloegel, E. L., Mansour, N. S. and Khalaf, G. I. (1955): A new concentration technic for the demonstration of Protozoa and Helminth eggs in feces, Am. J. Trop. Med. Hyg., 4 (1), 23-28 
2) Ishizaki, T. (1970): Skin tests in filariasis and schistosomiasis, In: Sasa, M. ed., Recent advances in researches on filariasis and schistosomiasis in Japan, 331-352, University of Tokyo Press, Tokyo

3) Kamo, E., Minai, M. and Ishizaki, T. (1976): Studies on schistosomiasis japonica with particular reference to rectal biopsy, 1 Epidemiological investigation, specially referred to the skin test and COP test, Japan. J. T. M. H., 4 (3, 4), 179-188 (in Japanese with English abstract)

4) Melcher, L. R. (1943): An antigenic analysis of Trichinella spiralis, J. Infect. Dis., 73 (1), 31-40

5) Oliver-González, J. (1954): Anti-egg precipitins in the serum of humans infected with Schistosoma mansoni, J. Infect. Dis., 95, 86-91

6) Prata, A. (1957): Biópsia retal na esquistossomose mansoni, Serv. Nac. Educ. Sanit., Rio de Janeiro

7) Rose, G. A. and Blackburn, H. (1968): Cardiovascular survey methods, Monograph series No. 56, World Health Organization, Geneva

8) Yokogawa, M., Sano, M., Tsuji, M., Kojima, S., Iijima, T. and Ito, Y. (1969): Treatment of schistosomiasis japonica with Niridazole, Ann. New York Acad. Sci., 160 (2), 933-946

\section{日本住血吸虫症に対する EMBAY 8440 (Praziquantel) の臨床的使用経験}

$$
\text { 加茂 悦 } \text { 爾 }^{1} \cdot \text { 石 崎 達 }{ }^{2}
$$

西ドイッの Merck 及び Bayer A. G. により新たに開発された住血吸虫駆虫剤 EMBAY 8440 (Praziquantel）を日本住血吸虫症患者に対して使用し, その副作用を二重盲検法によりチェックした。同薬 剤の特徴は一日のみの経口投与ですむてとである。

対象は宿主体内の成虫生存の可能性ある皮内反応高閾值患者48名を抽出し，乙れを半数（24名）ず つのプラセボーと投薬群に二分した。各群はさらに 1 回投与, 2 回投与（各 6 名）および 3 回投与 （12名）の3 群に分けた。乙れら各群について副作用を検討し, 同薬剂使用時における耐容性の臨床 的評価を下した。一回投薬量は $20 \mathrm{mg} / \mathrm{kg}$ で食後直ちに水で内服させた。

1 回または 2 回投与群では副作用はほとんどなかったが，3 回投与群ではかなり増えた。主な副作 用は二つあり, 第一は頭重または眠気などの中枢神経系の自覚症状と, 第二は一過性の軽度の貧血で あった。

しかしながら，耐容テストの評価では，不良は 1 例むなかった。評価優秀の症例数は対照群に対し EMBAY 投与群が少数であったが，評価良好の症例数は対照群より EMBAY 群の方が有意に多かっ た。

従って，この新薬は自覚症状と造血機能に注意すれば，臨床的に使用し得ると結論できた。ただし 本研究では対象の検便排卵者が少なく, しかむ微量排卵のため, 駆虫効果の判定は他の研究に期待し た。

本研究の意義は, 住血吸虫症患者に対して EMBAY 8440 を将来一般的に使用し得る基礎と展望を 与えた事にある。

1 巨摩共立病院内科, 山梨県櫛形町

2 独協医科大学アレルギー内科 